\title{
Islamist Women as Candidates in Elections: A Comparison of the Party of Justice and Development in Morocco and the Muslim Brotherhood in Egypt
}

\author{
Katarína Škrabáková \\ Comenius University in Bratislava, Department of Political Science \\ katarina.skrabakova@uniba.sk
}

\begin{abstract}
This paper examines the legislative recruitment of women from conservative Islamist parties. It questions the common assumption that generally all Islamist parties are equally hostile to political participation and representation of women. For this purpose, two of the electorally most successful Islamist groups in the MENA region are compared, namely the Egyptian Muslim Brotherhood (Мв) and its Moroccan offshoot, the Party of Justice and Development (PJD). The article seeks an explanation for diverging trends in female candidacy between these conservative religious movements, using the traditional supply and demand model of candidate selection. It argues that the less centralized and the more institutionalized parties (as is the case with the PJD) seem to be better equipped to facilitate women's candidacy than the more oligarchic ones (the мв). In order to fully grasp the reasons behind the diverging trends in the nomination of female candidates from both Islamist parties, cultural factors are scrutinized as well. The article highlights the limits of the supply and demand model of candidate selection, which cannot explain instances of unexpected change in recruitment strategies based on external interference. Furthermore, it does not provide us the means to assess the impact of individual candidates' 'feminist credentials' on overall female representation.
\end{abstract}

\section{Keywords}

Islamist parties - female candidacy - institutionalization - centralization participation 


\section{Introduction}

Participation of women throughout the Arab world has been steadily on the rise since the 1990s. Moderate Islamist movements and parties, mainly the offshoots of the Muslim Brotherhood (al-Ikhwān al-Muslimūn), have been some of the most important actors to mobilize around gender issues. These socially conservative religious-political movements, which share some specific ideological gender-related features, namely the idea of divinely inspired complementarity and a patriarchal sexual division of labour, tend to exhibit low levels of women's descriptive political representation. ${ }^{1}$ Women thus rarely represent these parties in elected bodies. However, public visibility of female Islamists, their participation in internal decision-making, and their generally prescribed roles within the Islamist parties vary across different political, socio-economic, and cultural contexts. ${ }^{2}$ By comparing the Moroccan Party of Justice and Development (PJD, Hizb al-Adāla wa-l-Tanmiya) and the Muslim Brotherhood ( $\mathrm{MB})$ in Egypt, I attempt to explain why the Moroccan PJD recruits far more women as candidates in elections than the мв. Previously, a country's electoral system and its level of socio-economic development, reflected in such indicators as female education and labour force participation, were attributed the central role in women's electoral candidacy and representation. ${ }^{3}$ However, these factors are fairly similar in both Morocco and Egypt. Interestingly, even in a particular country, various Islamist parties may develop fairly different approaches to internal empowerment of women and their nomination in elections. Thus the approach opted for in this article considers both the external factors at play and the intra-party ones. In order to compare the electoral experience of Islamist women from the PJD in Morocco and the MB in Egypt, the argumentation is based on the model of supply and demand in candidate selection. ${ }^{4}$ The first part introduces the 'demand-side' factors, most notably the level of intra-party centralization and institutionalization, which influences political gatekeepers when they evaluate candidates. The

1 Lihi Ben Shitrit, Righteous Transgressions: Women's Activism on the Israeli and Palestinian Religious Right (Princeton, NJ: Princeton University Press, 2015), 181.

2 Mona Tajali, "Islamic Women's Groups and the Quest for Political Representation in Turkey and Iran", The Middle East Journal 69, no.4 (2015), 563-81<https://muse.jhu.edu/ article/595954>.

3 Miki Caul, "Women's Representation in Parliament. The Role of Political Parties", Party Politics 5, no.1 (1999), 79-98, doi:10.1177/1354068899005001005; Andrew Reynolds, "Women in the legislatures and executives of the world: Knocking at the highest glass ceiling”, World Politics 51, no.4 (1999), 547-72, doi:10.1017/Soo43887100009254.

4 Pippa Norris and Joni Lovenduski, Political recruitment: Gender, race and class in the British Parliament (Cambridge: Cambridge University Press, 1995), 14. 
second part investigates the main 'supply-side', or ideological, factors, namely the cultural context and the party's ideology. The final part of the paper surveys in more detail the extent of the actual difference between the Islamist PJD and the мв in candidacy and subsequent representation of women, and suggests limits to the otherwise helpful model of supply and demand in candidate selection.

From the point of comparability of both Islamist groups, a few methodological issues arise. While the Moroccan regime has approached $i k h w a \bar{n} \bar{\imath}$ Islamists in a more tolerant fashion and has enabled them to form a legal political party, the PJD, the Egyptian regime never allowed the мв to legalize a political party, except for during a brief period in 2011-13. Although legality and organizational type (party vs social movement) are analytically important, I have chosen the electoral method and relative success in elections of both groups as starting points for comparison, the reason being that these are especially important when analysing the political participation and representation of women.

\section{Factors Influencing the Candidacy of Islamist Women}

Theoretical research suggests that the larger the pool of potential women candidates who are either local party activists or members of women's sections, or hold office in internal party structures, the more pressure they will exert on the leadership to support them as candidates, and the more likely it is that they will eventually institutionalize these gains. ${ }^{5}$ Indeed, participation rates of women in Islamist parties and movements are exceptional compared to other political parties in place. Yet their numbers alone and organization in separate sections have failed to empower women internally and have failed to translate into sustainable electoral gains. In this respect, the PJD in Morocco has recorded a much higher proportion of female candidates and MPs than the MB in Egypt, albeit mostly as tokens supported by the party in order to appear more inclusive. To illustrate, the Islamist PJD has the largest absolute number of women in parliament and the highest male-to-female ratio of its MPs (14.3 per cent of total seats in 2002, 12.7 per cent in 2007, 16.8 per cent in 2011, and 19.2 per cent in $2016^{6}$ ), while the мв has historically nominated only a handful of women. The following section will point to the possible factors influencing the difference in recruitment of women between the parties.

5 Caul, “Women's Representation", 83.

6 Interparliamentary Union, "MоRосcо: Majliss-annouwab (House of Representatives)" <http://www.ipu.org/parline/reports/2221_A.htm>. 


\section{Demand-side Factors in Islamist Women's Candidacy}

Recruitment and selection of political elites is entirely vested in political parties, which act as gatekeepers. ${ }^{7}$ Therefore, the party-specific rules and practices for fielding candidates influence the countrywide representation of women. Two characteristics related to party structure as outlined by Caul seem to be the most intimately connected to the candidacy of women. ${ }^{8}$

The first is the level of centralization, whereby the hierarchy and control over decision-making facilitates opportunities for women. Smaller groups of elites can be more easily pressured to empower women, compared to decentralized parties with various power centres. However, the oligarchic control of the party is seen both as indispensable and beneficial for the resulting balanced nomination on party lists and/or safe constituency seats, mainly in a democratic setting. ${ }^{9}$ This outcome is assured by the non-inclusive, top-down appointment by the party central command, which is able to enforce positive discrimination of vulnerable social groups (e.g. women, minorities, etc.) as a corrective measure. However, this study shows that within non-democratic regimes and overly patriarchal political parties, the more centralized, inaccessible, and oligarchic the leadership of the party, the less likely it is to nominate women in elections. This is mostly because the level of centralization in an authoritarian setting is often a mere function of the overall regime repression. Centralization of a party or movement therefore works as a way to mitigate the pressure from the government. In fact, within patriarchal, non-democratic regimes, what matters more for the representation of women is the centralization of selection and nomination procedures within the party. Thus it is reasonable to assume that mixed systems, whereby the recruitment starts at the bottom level but is subjected to the interference of the leadership in the final decision about the composition of party lists, is more suitable for the enhanced nomination of women in candidate lists than either centralized or decentralized recruitment per se.

The second factor proposed by Caul is the degree of institutionalization. ${ }^{10}$ Theoretically, the rule-oriented procedures within the party empower women

7 Caul, “Women's Representation”; Sheri Kunovich and Pamela Paxton, "Pathways to Power: The Role of Political Parties in Women's National Political Representation", American Journal of Sociology 111, no.2 (2005), 505-52, doi:10.1086/444445; Michael Gallagher and Michael Marsh, Candidate selection in comparative perspective. The Secret Garden of Politics (London: Sage, 1988), 1.

8 Caul, "Women's Representation", 8 o.

9 Richard Katz and William Crotty, eds., Handbook of Party Politics (London: Sage, 2006), 115 .

Caul, “Women's Representation”, 81. 
in terms of monitoring. By participating in activities of party congress, female members are able to mobilize to elect women into higher echelons of the party and propose female candidates to elections. They are also better positioned to institutionalize these gains within the party, creating even more lasting effects on the representation of women. ${ }^{11}$ However, weakly institutionalized parties have by-laws which are rarely applied, and the authority rather resides in traditionalist or charismatic leadership. Dominated by a small group, patronageoriented parties often seclude women to isolated caucuses. This especially applies to the socially conservative religious parties' exclusive structures, which are less favourable to women's empowerment.

Similar indicators of women-friendly recruitment structures have been identified by Scarrow. ${ }^{12}$ The author studied intra-party democracy, which is usually understood as a precondition to a more equal representation of women in candidate lists. Of all party factors, she stressed the importance of democratic inclusiveness, and a certain amount of decentralization and formalization. Furthermore, Brichta and Brichta show that women's sections inside political parties can only be successful if women effectively lobby the party's leadership. ${ }^{13}$ Whether the party nominates and empowers more women is thus also seen as being dependent on the degree of internal pressure (e.g. women's agency). If women are effectively organized in the party and lobby for representation and women-friendly mechanisms in the party's by-laws, they are more likely to succeed. ${ }^{14}$

\section{Supply-side Factors in Islamist Women's Candidacy}

The gender study literature tends to agree that women exhibit a much lower interest in running for political office compared to men. In their self-evaluation, women often cited a lack of confidence, qualifications, funds, and contacts, which according to Fox and Lawless stem from the traditional sex-role

$11 \quad$ Ibid., 94 .

12 Susan Scarrow, Political Parties and Democracy in Theoretical and Practical Perspectives: implementing intra-party democracy (Washington DC: National Democratic Institute for International Affairs, 2005), 7-11 <https://www.ndi.org/sites/default/files/1951_polpart_ scarrow_110105_5.pdf>.

13 Avraham Brichta and Yael Brichta, "The Extent of the Impact of the Electoral System upon the Representation of Women in the Knesset", in Electoral Systems in Comparative Perspective: Their Impact on Women and Minorities, eds. Wilma Rule and Joseph F. Zimmerman (Westport, Conn: Greenwood Press, 1994), 115-26.

14 Richard E. Matland, "The Representation of Women in Political Parties in Central and Eastern Europe" (paper presented at the European Consortium for Political Research Joint Sessions of Workshops, Uppsala, 13-18 April 2004). 
socialization and gender-specific family roles and expectations. ${ }^{15}$ The supply side of women as political candidates is therefore commonly highly skewed. Additionally, in many societies the political sphere is considered, to a varying degree, to be improper, immoral, and corrupt, which eventually drives the party leaders to see women candidates as a liability. Popular attitudes about gender equality thus inform the decisions of the party's leadership during the nomination stage. ${ }^{16}$ If the public views gender equality as an important issue, gatekeepers will try to prove the party is attentive to those concerns. Indeed, the impact of religion and prevailing gender ideology has been proven by numerous studies to coincide with the number of women in national legislatures. ${ }^{17}$ Paxton and Kunovich argue that ideological factors, unlike political or socio-economic ones, simultaneously influence both the supply of and demand for women..$^{18}$ On the supply side, ideological beliefs may influence women's decision to run for political office, regardless of their careers or levels of education. On the demand side, ideological beliefs may influence whether voters accept women and therefore may also influence whether parties decide to select and support female candidates. To conclude, both external and internal factors are critical for the creation of a women-friendly environment in the party, which in turn has repercussions for their nomination and subsequent political representation.

\section{Demand-side Factors in the Candidacy of Islamist Women}

\section{Organizational Structure of the PJD}

In order to explain the relative success of the PJD in terms of candidacy and political representation of women, the patterns of its internal participation need to be scrutinized. Let's consider first its level of centralization. The PJD adopted its by-laws in a new charter passed in 2004. In the process, the powers

15 Richard L. Fox and Jennifer L. Lawless, "Entering the Arena? Gender and the Decision to Run for Office", American Journal of Political Science 48, no.2 (2004), 264-8o, doi:10.2307/ 1519882.

Louise K. Davidson-Schmich, "Implementation of political party gender quotas: Evidence from the German Länder 1990-2000", Party Politics 12, no.2 (2006), 211-232, doi:10.1177/ 1354068806061338 .

17 Pamela Paxton and Sheri Kunovich, "Women's Political Representation: The Importance of Ideology", Social Forces 82, no.1 (2003), 87-113 <http://www.jstor.org/stable/3598139>; Pippa Norris and Ronald Inglehart, "Cultural Obstacles to Equal Representation", Journal of Democracy 12, no.3 (2001), 126-40, doi:10.1353/jod.2001.0054.

Paxton and Kunovich, “Women's political representation”, 103. 
vested in its general secretariat were curtailed, and more transparent competences for all the bodies were established. Furthermore, since 2004 the local secretariats have been empowered in an effort to decentralize internal decision-making. The party's leadership is therefore less autonomous and more accountable to their grassroots. ${ }^{19}$ This trend also influenced the party's procedures for selecting candidates.

In order to downplay the accusations of Moroccan parties selecting female candidates based on patrimonial linkages to the leadership, only the PJD and the Istiqlāl party have implemented formal selection criteria to determine candidates on their national lists. This formalization later results in the election of more qualified female candidates, such as I'timād Zāhīdī (Itimad Zahidi), who has been on the local council of Timāra (Temara) since 2009 and is a member of the PJD's Central Election Commission. ${ }^{20}$ The nomination generally follows three phases. During the first phase, candidates are nominated by the local offices, where their final number is reduced to three. After that, potential candidates need to be approved by the regional bodies before being scrutinized by the upper echelons of the party. During this last stage, the secretary general has the power to reject at least a third of the candidates, although he has to justify his decision. It is exactly at this stage where the central organs may intervene to balance the list of candidates to reflect the goals of the party regarding gender. $^{21}$ Additionally, the PJD reportedly uses financial incentives for local secretariats in order to motivate them to place women in the secure slots on the electoral tickets. This policy stems from the contagion effect of other parties and from the PJD's desire to enhance its public image, as well as from the introduction of mandatory quotas to the local elections, through which the party seeks to remain competitive. To sum up, the PJD's legislative recruitment starts at the bottom level but is subjected to interference by the leadership, which theoretically facilitates female candidacy.

Second, the PJD is fairly institutionalized. Already in 2004 the PJD's social movement, the Movement for Unity and Reform (MUR, Harakat al-Tawhìdwa'lIșlāh), organized a meeting of the consultative assembly during which it was decided that activities of the movement and the party should be differentiated yet subject to cooperation (or "partnership", sharāka). ${ }^{22}$ Formal separation was

19 Eva Wegner, Islamist Opposition in Authoritarian Regimes (Syracuse, NY: Syracuse University Press, 2011), 138.

20 Kathleen Meradith, Female Representation in Morocco's House of Representatives (IndependentStudy Project (ISP) Collection, paper, 2014) <https://www.academia.edu/10149404 /The_Political_Gender_Filter_the_reality_of_Moroccos_national_list_quota $>$.

21 Author's interview with prominent member of PJD, Rabat, July 2013.

22 Feriha Perekli, "The Applicability of the 'Turkish Model' to Morocco: The Case of the Parti 
finalized in the document "Political participation and the relationship between the movement [MUR] and the party [PJD]", published in 2006. Movement and party currently complement each other in terms of agenda but are functionally separate. The PJD thus has an actual autonomy in leadership, finances, and selection procedures for the top-ranking positions within the party. ${ }^{23}$ The PJD's nationwide congress is held regularly, and the party follows formal procedures as defined in its fixed and accessible by-laws. Interestingly, all major internal decisions taken by the party since the adoption of by-laws in 2004 have been consulted by the party congress. ${ }^{24}$ The extent of the formalization of internal practices is also fittingly illustrated by the replacement of the party's long-term secretary general, Sad al-Dīn al-Uthmānī (Saad Eddin al-Uthmani), by the current leader, 'Abd al-Ilāh Binkīrān (Abdelilah Benkirane), during the nationwide congress in 2008 and by the open criticism that preceded this election. ${ }^{25}$

When addressing the particular issue of legislative recruitment by the Islamist PJD, we need to assess carefully the structure of opportunities given by the party to women, which influences whether women decide to participate and become politically active. Similar to other Moroccan parties, the Islamist PJD set up an internal 15 per cent quota for women in its regional offices. ${ }^{26}$ According to a prominent member of the PJD, Laḥsan al-Dāwūdī (Lahcen Daoudi), women currently make up around 15-20 per cent of the whole membership, reflecting their percentage in the workforce. ${ }^{27}$ Additionally, as the PJD leaders often boast, in 2012 the party institutionalized a 20 per cent quota for youth and has more than 25 per cent of female representatives in the Shürā national council. ${ }^{28}$ Currently, only two women serve in the executive general secretariat, even though it is still far more progressive compared to the Muslim Brotherhood in Egypt. However, the Moroccan secular parties, such as Istiqlāl, the USFP, and the Party of Progress and Socialism (PPS), have given women

de la Justice et du Développement (PJD)", Insight Turkey 14, no.3 (2012), 85-108, 98 <http:// file.insightturkey.com/Files/Pdf/insight_turkey_vol_14_no_3_2012_perekli.pdf>.

23 Hussam Tamam, "Separating Islam from Political Islam: The Case of Morocco", Arab Insight 1, no.1 (2007), 99-112, on 101.

24 Wegner, Islamist Opposition, 108.

25 Author's interview with prof. Ashraf El-Sherif, American University in Cairo, November 2012.

26 Najlae Benmbarek, "La politique sous le voile", Maroc Hebdo, 11 October $2002<$ http:// www.maghress.com/fr/marochebdo/52817>.

27 Laurel Rapp, "The Challenges and Opportunities Moroccan Islamist Movements Pose to Women's Political Participation" (Center for the Study of Islam and Democracy, 2008) <https://www.csidonline.org/9th_annual_conf/Laurel_Rapp_CSID_paper.pdf $>$.

28 Author's interview with prominent member of PJD, Rabat, July 2013. 
more space within the party structures. For instance, Istiqlāl assigns 20 per cent of its executive committee to women (roughly 20 seats), while the socialist USFP assigns 20 per cent of the seats in its internal congress to women. ${ }^{29}$ The PJD's institutionalization helped its female members enlarge intra-party positions and as a result influence the growing trend in female candidacy of PJD women in legislative elections. However, the internal participation of women is still influenced by the party's patriarchal norms and overall conservative ideology. ${ }^{30}$

\section{Organizational Structure of the Muslim Brotherhood}

The organizational structure of the мв in Egypt differs significantly from that of the PJD. First, in contrast to the PJD's relative transparency, the MB still functions as a secretive, underground movement, with varying levels of overt activities, responding to the degree of government repression, which has changed dramatically over the years since the MB's founding in 1928. The regime's systematic repression affected the movement's design and ensured extreme centralization of decision-making and decentralization of implementation, resembling Leninist democratic centralism. ${ }^{31}$ The basic organizational unit of the мв is the usra (cell), supervised by the Brotherhood's regional administration. At the tip of the pyramid, the most important body is the Guidance Bureau (Maktab al-Irshād), presided by the Supreme Guide (al-Murshid $a l-\bar{A} \mathrm{~mm}$ ), the leader of the Muslim Brotherhood. The Guidance Bureau is elected via the Majlis al-Shūrā (lit. "Consultative Council", hereafter Shūrā Council). However, traditionally only prominent members were elected, creating a system in which only an increasingly gerontocratic group of conservative loyalists have the upper hand. The Shūrā Council is formally elected on a regular basis, but state repressions have usually thwarted its meetings. ${ }^{32}$

Since its establishment, the мв has resisted changes to its recruitment structures. The general working formula is based on the usra system, in which loyalty and trust are paramount. Aspiring members undertake up to four years of socialization and indoctrination before becoming active members, much

29 Rapp, "The Challenges and Opportunities", 8.

30 Fatima Sadiqi, "Morocco", in Women's rights in the Middle East and North Africa: progress amid resistance, eds. Sanja Kelly and Julia Breslin (New York: Freedom House and Rowman \& Littlefield Publishers, 2010), 311-36.

$3^{1} \quad$ Ashraf Nabih El-Sherif, "Democratization of Islamist Movements in Egypt and Morocco: Political Opportunities, Organizational Frameworks, and the Ideological Marketplace" (PhD diss., Boston University, 2011), 290.

32 Mona El-Ghobashy, "The Metamorphosis of the Egyptian Muslim Brothers", International Journal of Middle East Studies 37, no.3 (2005), 373-95, 377, doi:10.1017/Soo20743805052128. 
like in any other clandestine movement. ${ }^{33}$ The high level of scrutiny of its members is in sharp contrast to the experience of the PJD, especially since 2004. It was inspired both by the huge degree of repression against the movement, as well as by Ḥasan al-Bannā's vision of the jamāa (society) as an association based on solidarity, brotherhood, discipline, and zeal. ${ }^{34}$ The long-term process of acceptance to the movement, and financial, social, and familial relations between its members, may explain why only a few hundred members left the movement prior to 2011. However, during the Arab Spring, the limited participation frustrated a significant portion of мв youth, who defected to other political Islamist groups. ${ }^{35}$ Similarly, the recent wave of repression has reportedly prompted widespread defections from the Egyptian мв.

In order to escape criticism and challenges, the мв compensated for the lack of internal participation in decision-making by fostering a strong sense of common cause and loyalty. However, this does not fit with the idea of traditional party institutionalization. The $\mathrm{MB}$ has lacked full transparency mainly due to the need for secrecy and an organizational culture that rewarded loyalty, not critical thinking. To illustrate, since the 1930s the мв has published documents about organizational guidelines, rules, and regulations. However, unlike in the case of the PJD, agreed by-laws did not empower the wider membership vis-à-vis the leadership, prompting internal criticism of lack of openness and accountability in the organization. Since the mid-200os, the мв has reportedly sought to counter this image by holding internal elections, by allowing active members a greater role in selecting their representatives, and by enhancing internal procedures of accountability. ${ }^{36}$ However, the problem of lack of alternation and turnover in critical decision-making positions, particularly in the Guidance Bureau, has remained. Even though the organization's local and regional levels have traditionally retained a high degree of freedom to elect their representatives, the MB's strict party discipline, the subordination of majority to minority, and the absolutely binding decisions of the Guidance $\mathrm{Bu}-$

33 Eric Trager, "The Unbreakable Muslim Brotherhood: Grim Prospects for a Liberal Egypt", Foreign Affairs 90, no.5 (2011), 114-26 <http://www.jstor.org/stable/23041781>. Brynjar Lia, The Society of the Muslim Brothers in Egypt, 1928-1942 (Reading: Ithaca, 1998), 53-54.

35 Jeffrey Martini, Dalia Dassa Kaye and Erin York, The Muslim Brotherhood, Its Youth, and Implications for U.S. Engagement (Santa Monika: National Security Research Division, RAND Corporation, 2012), 9.

36 Khalil Anani, Inside the Muslim Brotherhood: Religion, Identity, and Politics (Oxford: Oxford University Press, 2016), 116-17. See also Carrie Rosefsky Wickham, The Muslim Brotherhood: Evolution of an Islamist Movement (Princeton, NY: Princeton University Press, 2015), 152. 
reau on all the lower bodies of the movement and its members are more reminiscent of democratic centralism than of institutionalized democratic accountability.

Accordingly, the lack of formal mechanisms directly weakens the bargaining power of female members of the мв under the umbrella of the Muslim Sisters (Qism al-Akhawāt al-Muslimāt). Unlike other MB's sections, the Muslim Sisters have no formal organizational structure from which to apply direct pressure on the upper leadership. Women of the мв are crucial in recruiting new female voters from conservative families, but their significance beyond campaigning, as candidates in elections or members of executive bodies, is extremely limited. ${ }^{37}$ However, this has not always been the case. In the past, especially during "the era of tribulations" (mihna) under the Nasser regime (1954-70), women of the мв were crucial in maintaining the organization. For instance, the мв-affiliated Society of Muslim Women became the only group outside the reach of government repression to coordinate relief efforts for imprisoned brothers. ${ }^{38}$ This situation can be, to a certain degree, likened to a new window of opportunity for Muslim Sisters following the current wave of repression targeting the whole male leadership of the Muslim Brotherhood.

The Sisterhood was established soon after the movement's creation in 1928. From its establishment, Supreme Guide Ḥasan al-Bannā acted as its general director with the power to appoint his male secretary. This system of male 'guardianship', where the leader of the section and his deputy are men who act as liaisons between the Muslim Sisters and the Guidance Bureau, still remains. Even though the Sisterhood is internally managed by 12 elected female representatives, all financial, personnel, and membership qualifications are run according to the guidelines approved by the Guidance Bureau. ${ }^{39}$ The same applies to general guidelines directing the Muslim Sisters' social activities and overall mission. Additionally, none of the 17 members of the Guidance Bureau has ever been a woman. Women can neither vote for party leaders in the Shūrā Council nor serve on top committees. ${ }^{40}$ They have been mostly confined to a separate organization that has no overlap with the internal structures and as

37 Omayma Abdel-Latif, In the Shadow of the Brothers: The Women of the Egyptian Muslim Brotherhood, (Washington DC: Carnegie Endowment for International Peace, Carnegie Papers nr.13, 2008) <http://carnegieendowment.org/files/women_egypt_muslim_brother hood.pdf>.

38 Ghada Hashem Talhami, The Mobilization of Muslim Women in Egypt (Gainesville: University Press of Florida, 1996), 51.

39 Talhami, Mobilization, 47.

40 Gamze Çavdar, "Islamist rationality: an assessment of the rational choice approach", Politics and Religion 5, no.3 (2012), 584-608, on 599, doi:10.1017/S1755048312000314. 
such can hardly influence decision-making inside the MB or the candidate selection procedure. While the issue of female non-representation in the Guidance Bureau has been raised, it is still left open. ${ }^{41}$

The problem of extremely low intra-movement participation of women is not confined to the conservative Islamist мB. In fact, it applies to all other Egyptian parties. For instance, the oldest liberal party in Egypt, Hizb al-Wafd, claims to have only 2 per cent of its total membership as female, which implies that women also play a marginal role inside the party's decision-making structures. Formerly leftist, then Islamist-turned, the Labour Party (Hizb al-'Amal) did not have more than two women on its higher committee. Only the socialist al-Tajammu' party claims to have reserved ten seats on its central committee for women. ${ }^{42}$ However, the specific lack of formal intra-party mechanisms within the $\mathrm{MB}$ weakens the bargaining power of its female members and dissuades them from pushing for a more active role within the movement, as well as externally. Evidently, the only way that Muslim Sisters may apply pressure on the leadership is through personal relationships, as they are mostly the wives, sisters, or daughters of senior Brotherhood leaders.

\section{Supply-side Factors in the Candidacy of Islamist Women}

\section{Cultural Context in Morocco as a Driver or Inhibitor of the Supply of Women}

According to Sater, the marginalization of women in politics in Morocco can generally be traced to several factors: the political culture regarding women's participation, the perceived absence of voters' support, and a lack of financial means. ${ }^{43}$ Most of the incremental advances for Moroccan women in politics have taken place from above, through "state feminism." The turning point regarding women's political activism occurred in 1999, when the modernist King Muhammad VI assumed power. His pro-feminist stances played a vital role in pushing through the groundbreaking reform of the Family Code, which granted women significant rights in terms of marriage, divorce, and limits on

41 IkhwanWiki - The Official Historical Encyclopaedia of the Muslim Brotherhood, "Al-Akhawāt al-Muslimāt wa-Maktab al-Irshād wa-Majlis al-Shūrā", undated <http://tinyurl. com/hawglat>.

42 Hala Mustafa, Abd al-Ghaffar Shukor, and Amre Hashem Rabi', Building Democracy in Egypt (Stockholm: International IDEA, 2005), 24.

43 James N. Sater, "Changing Politics from Below? Women Parliamentarians in Morocco", Democratization 14, no.4 (2007), 723-42, on 730, doi:10.1080/13510340701398352. 


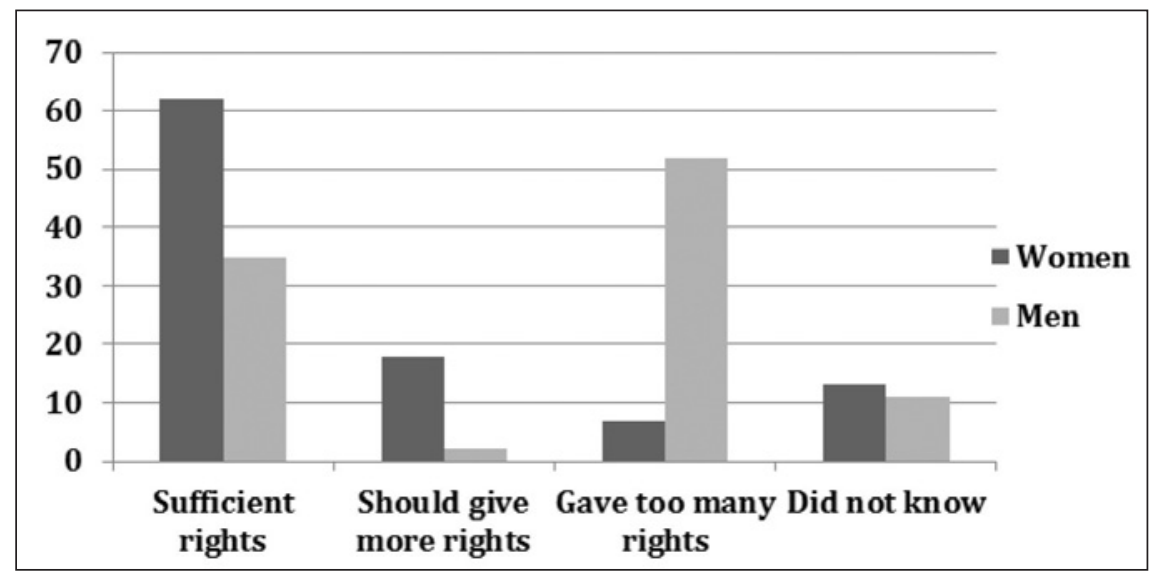

GRAPH 1 Satisfaction with the reform of the Family Code

a Source: IFES. Focus on Morocco. Opinions on the Family Law and Gender Quotas, Topic Brief, 22 June $2010<$ http://womeninscience.rasit.org/files/Moroccofamilylaw.pdf>.

polygamy. ${ }^{44}$ However, the progressive steps towards gender equality are constantly being contested on account of the social reality of traditionalist Moroccan society. On the one hand, the views of the public may well be more progressive than the country's laws. When looking at the latest results of the World Values Survey, we find that when asked whether Moroccans agree that "women have the same rights as men", overall results reached 7.9 points (where 10 means "Completely agree"). ${ }^{45}$ Interestingly, this score is the highest among all Arab countries. When looking at the views on specifics of the Family Code, however, we encounter a huge gender gap. What is even more striking is that the majority of women consider the current form of the Family Code to be satisfactory (Graph 1), even though the reform left many issues, such as equal inheritance, family duties, and violence against women, unresolved. This suggests that Moroccan society is still relatively traditionalist regarding gender relation issues, albeit less conservative than many other Arab states, including

44 Francesco Cavatorta and Emanuela Dalmasso, "Liberal outcomes through undemocratic means: the reform of the Code de statut personnel in Morocco", Journal of Modern African Studies 47, no.4 (2009), 487-506, doi:10.1017/Soo22278Xo9990164.

45 World Values Survey/Data \& Documentation/Online Analysis <http://www.worldvalues survey.org/WVSOnline.jsp>. 
Egypt. These very same factors in turn influence the strategic calculations of potential candidates on whether or not they feel equipped to run for office. ${ }^{46}$

\section{The PJD's Ideology and its Effect on Supply of Women}

Female members of the PJD still face enormous obstacles in reaching key internal decision-making structures, namely the general secretariat or Shūrā Council. This is either because of their personal detachment from higher politics, patriarchal traditions, or resistance from male leadership. ${ }^{47}$ As one female representative of the PJD stated, "Our activists are pretty representative of Moroccan society. [...] Some among them don't yet accept that women should hold positions of responsibility." 48

Female members of the PJD are formally organized inside a parallel women's section - the Organization for the Renewal of Women Awareness (ORWA, Munazzamat Tajdìd al-Wa'y al-Nisā̄ $)$. In order to present the PJD party as being continually less dogmatic, the leader of orwa, Basīma al-Ḥaqqāwī (Bassima Hakkaoui) argues that, unlike the мв in Egypt, the PJD does not consider Islam as its religious and political programme. She specified the PJD's goals as national development reconciled with Moroccan cultural and religious traditions, where neither "secular" nor "Islamist" captures fittingly its political ideology. ${ }^{49}$ Yet her women's section's use of traditional religious vocabulary and conservative division of gender roles is fairly apparent. ORWA officially aims to "preserve authenticity and Islamic identity" in relation to women and implement "women's rights in conformity with the sharía." It stresses the need for "validation of the role of the wife [...] in the preservation of family cohesion and instruction of wives in their rights and duties according to the teachings of Islam." And it calls for "the adoption of laws in conformity with the vision of Islam in all areas of women's lives." 50

Such a division of labour inside a political party is not exclusively related to Islamists. For instance, the secular PPS created its women's section in 1985 un-

46 Mona Lena Krook, "Why are Fewer Women than Men Elected? Gender and the Dynamics of Candidate selection", Political Studies Review 8, no.2 (2010), 155-68, on 158, doi:10.111/ j.1478-9302.2009.00185.x.

47 Julie Elisabeth Pruzan-Jørgensen, Islamic Women's Activism in the Arab World: Potentials and challenges for external actors (Copenhagen: Danish Institute for International Studies, DIIs Reports, 2012) <http://www.diis.dk/node/1594>.

48 Cited in Rapp, "The Challenges and Opportunities", 22.

49 Doris H. Gray, Beyond Feminism and Islamism: Gender and Equality in North Africa (London: Iв Tauris, 2014), 123.

50 Souad Eddouada and Renata Pepicelli, "Morocco: Towards and Islamic State Feminism", Critique internationale no 46, (2010/1), 87-100, on 96; doi: 10.3917/crii.046.0087. 
der the label of the Democratic Organization of Moroccan Women, and two years later the Istiqlāl party followed suit with the Organization of the Istiqlāl Women (OFI). ${ }^{51}$ However, the Islamically sanctioned design of a separate section for women creates barriers to their political activities, as women are supposed to act within the boundaries of 'women's issues' as set out by the patriarchal male-dominated structures of the party. It also results in the segregation of women inside the party. ${ }^{52}$ As al-Ḥaqqāwī argues, women "should, just as men, engage in all debates that affect society", not just "issues that affect them as women." ${ }^{33}$ Several experiments show that separating women in a specific organization often condemns them to occupy themselves only with the issues that affect them as women. Nevertheless, in contrast to other Islamist movements, such as the Yemeni Congregation for Reform (al-Ișläh, Tajammuc al-Yamani li-l-Ișlāh), Hamas in Palestine, and the Mв in Egypt, the PJD does not have restrictive rules about gender mixing and female public activities. ${ }^{54} \mathrm{Al}-$ Haqqāwī further elaborates that women should engage more in public debates, not just in those that concern them as women. She also admitted that although the party utilizes her high-profile image in public, within internal meetings her position is often questioned. ORWA's lack of concrete steps in empowering women may be ascribed to its unwillingness to alienate important men within the party. ${ }^{55}$ As al-Haqqāwì claims, it is not the patriarchy of society that reflects into politics; on the contrary, "society is demanding greater rights for women, while there are some men in positions of power who have a problem sharing this political power with women."56

\section{Cultural Context in Egypt as a Driver or Inhibitor of the Supply of Women}

In contrast to the situation in Morocco, Egyptian women have struggled for years to assert themselves as parliamentary candidates. The lack of women's representation has been attributed to the highly patriarchal culture, the weakness of opposition parties, the neo-patrimonial regime (which did not favour

\footnotetext{
$5^{1} \quad$ Rapp, "The Challenges and Opportunities", 8.

$5^{2}$ Janine A. Clark and Jillian Schwedler, "Who Opened the Window? Women's Activism in Islamist Parties", Comparative Politics 35, no.3 (2003), 293-312, on 302; doi:10.2307/4150178.

53 Cited in Rapp, "The Challenges and Opportunities", 25.

54 Wegner, Islamist Opposition, 54.

55 Gray, Beyond Feminism, 123.

$5^{6}$ Siham Ouchtou, "Some Politicians See Women as Intruders. Interview with Morocco's Minister Bassima Hakkaoui", Qantara, 24 February $2012<$ http://en.qantara.de/content/ interview-with-moroccos-minister-bassima-hakkaoui-some-politicians-see-women-asintruders>.
} 
women's representation), and the wave of Islamic revivalism that has affected the region since the 1970s. In recent years, conservative salafi movements have also made inroads, partly in competition with the MB. Both movements emphasize, to a varying degree, gender division of roles, where women are seen mostly as mothers and wives confined to the household. Family honour, social stigmatization, pressure, threats, and intimidation by relatives and society have all contributed to Egyptian women's low level of political activism. ${ }^{57}$ The Egyptian regime reflected these social changes by resisting meaningful change to women's status in the shari'a-dominated Family Code. In 2000, women were granted the right to apply for a no-fault divorce. ${ }^{58}$ However, these reforms to personal status were termed “Suzanne's laws”, after President Husnī Mubārak's wife, who headed the National Council on Women. ${ }^{59}$ This way, conservative opponents of these incremental reforms tried to discredit the law in order to return to the more conservative interpretation of Islamic shari'a advocated by the мв. Due to the conservative attitudes of civil society and the lack of progress associated with women's rights, Egypt has been ranked among the worst Arab states for women. ${ }^{60}$ Weak social support for enlargement of basic women's rights can thus be interpreted as one of the decisive factors limiting Egyptian women's decision to participate and subsequently run for office.

\section{The Muslim Brotherhood's Ideology and Its Effect on the Supply of Women}

Male members often justify the gender inequalities inside the Brotherhood by the need to protect women from state repression. Their position mirrors pre.

57 Mariz Tadros, "Quotas: A Highway to Power in Egypt... But for Which Women?", IDS Bulletin 41, no.5 (2010), 89-99, on 93, doi: 10.1111/j.1759-5436.2010.00170.x.

$5^{8}$ The changes included the right to custody of their children for divorced mothers until they are 15 years old (instead of 9), changing the visiting rights of the non-custodial parent (usually the father), and allowing a no-fault divorce, which requires only that the woman return her dowry to her husband without having to prove harm, disabling injury, or abandonment.

59 Isobel Coleman, "Women and the Arab Revolts", Brown Journal of World Affairs 18, no.1 (2011), 197-210, on 203 <http://www.jstor.org/stable/24590794>.

60 The study was carried out by the Thomson Reuters Foundation, and the conclusions were reached by examining such data as violence against women, reproductive rights, the status of women - in the family unit, in society, and within the economy - and the quality of their political representation. "Factbox: Women's rights in the Arab world", Reuters, 22 November 2013 <http://www.reuters.com/article/us-arab-women-factbox-idUSBREgAB ooI20131112>; "POLL-Egypt is worst Arab state for women, Comoros best", Thomson Reuters Foundation, 12 November $2013<$ http://news.trust.org/item/20131108170910-qacvu/?source =spotlight-writaw $>$. 
vailing salafi views on women and their traditional roles as mothers and wives, not political leaders. ${ }^{61}$ This is evidenced by the movement's ideological platforms, which deny women the right to seek presidential office and stress "natural gender differences." ${ }^{2}$ According to the MB's electoral programmes, women's rights should be harmonized with the "fundamental values of the society", thus conforming to their conservative perception of Islam. ${ }^{63}$ Admittedly, several individual female figures promote the position of the Muslim Sisters. For instance, in 2007 Rasha Ahmed wrote an open letter to the Guidance Bureau asking for more political power for women inside the мв. Some reformist male members, such as Ișām al-'Aryān (Essam Erian), Muhammad Ḥabīb, and Ibrāhīm al-Za'farānī, supported this idea. The latter even attempted to nominate three women - Wafā Mashhūr, Makārim al-Dayrī, and Jīhān al-Ḥalafāwī - to the Shūrā Council, although unsuccessfully. ${ }^{64}$

After the ouster of President Ḥusnī Mubārak in 2011, the structure of opportunities for women inside the мв altered slightly. During the revolution and following the anti-Brotherhood coup in mid-2013, individual Muslim Sisters took to the streets and played an important part in organizing protests and sitins around the country, breaking many social taboos about the appropriate spaces for women and socially prescribed curfews. ${ }^{65}$ Concurrently, after the revolution, the Muslim Brotherhood was finally allowed to create its political party, the Freedom and Justice Party (FJP, Hizb al-Hurriyya wa-l-'Adāla), which paradoxically boasted over a thousand female co-founders out of seven thousand members, the largest ratio among all Egyptian political parties. The FJP's Women Committee, led by Ṣabāḥ al-Saqqārī, even opened several kiosks in

61 Abdel-Latif, In the Shadow, 14.

62 Interestingly, these traditionalist views are distributed across Egyptian society. In a survey undertaken by the UNDP, only 45.9 per cent of Egyptians stated that women should have the right to become prime minister, and only 25.7 per cent believed women should have the right to become head of state. Source: UNDP, The Arab Human Development Report 2005: Towards the Rise of Women in the Arab World (New York: UNDP, 2006) <http://hdr. undp.org/sites/default/files/rbas_ahdr2005_en.pdf, 94, 261>.

63 Abdel Monem Said Aly, Understanding the Muslim Brothers in Egypt (Waltham, MA: Crown Center for Middle East Studies, Middle East Brief 23, 2007), 4.

64 Omayma Abdel-Latif, "Women in Islamist movements", in Interregional challenges of Islamic extremist movements in North Africa, ed. Mona Abdalla (Pretoria: Institute for Security Studies, Monograph 180, 2011), 180-194, 181 <https://issafrica.s3.amazonaws.com/ site/uploads/Mono18o.pdf>.

65 Mariz Tadros, The Politics of Mobilising for Gender Justice in Egypt from Mubarak to Morsi and Beyond, (Brighton: Institute of Development Studies, IDs Working Paper 442, 2014), doi: 10.1111/j.2040-0209.2014.00442.x. 
Egypt in order to attract more women. ${ }^{66}$ Although the FJP strived to project an image of a moderate party open to women, all important decisions, including which candidates were selected, were in the hands of the Brotherhood rather than the party itself. Nonetheless, there was an intense discussion inside the FJP about the need to choose its own candidates. But before it could yield any results, the discussion was interrupted by the 2013 army coup, after which the dire situation for Islamist women resumed. ${ }^{67}$ The security threat, which had justified the seclusion of female мв members, had briefly disappeared but was now returned. How it will affect the intra-movement participation of women and their political representation in the future is still too early to predict.

\section{Beyond the Supply and Demand Model?}

The proportion and visibility of women inside the PJD has significantly increased in the last decades. Due to the PJD's decentralization and institutionalization, women are present and able to vote in, and exert pressure on, all decision-making bodies - the general secretariat, the Shūrā Council, and the general congress - regardless of their grievances or marginalization inside the party. This stands in sharp contrast to the experience of women inside the $\mathrm{MB}$ in Egypt. The relatively decentralized and institutionalized PJD thus enlarged the structure of opportunities for women within the party's decision-making structures, thereby facilitating the entrance of more female candidates during the Moroccan parliamentary elections. In comparison, because of its strictly centralized structure and lack of institutionalization, the мв leaves little room for women to prepare their own distinctive women's programme and rarely allows them to act as candidates in elections. The мв has relied on the Muslim Sisters mostly for recruitment and mobilization purposes during the elections. This decision may be partly attributed to prevailing gender ideology and the strict division of gender roles within the movement, but it also partly reflects the historical legacy of the мв as a socio-religious popular movement and the near absence in Egypt of a political structure in which a legal and modern Islamist political party can exist.

However, reflecting on the empirical cases, the very fact that the PJD nominates substantially more women than the $\mathrm{MB}$ is also based on other factors.

66 "FJP Women Committee Asserts Role of Women in the Nahda Project", IkhwanWeb: The Muslim Brotherhood's Official English Website, 14 May 2012 <http://www.ikhwanweb.com/ article.php?id=29985>.

67 Wickham, Muslim Brotherhood, 314. 
First, the PJD installed the voluntary gender quotas and nominated more women in order to convey the image of a modern and open party to escape opposition criticism. ${ }^{68}$ Second, the Moroccan government financially incentivizes parties to enlarge female membership bases and nominate women to elections, which has acted as a huge motivation for the PJD, as well as other parties in the system. Lastly, PJD leaders soon realized that female candidates may help the party win more mandates in parliament, especially under the reserved seats quota system, even if the leaders are not at ease with more women assuming positions of power. This is also influenced by the specific nature of the Moroccan monarchy, which sanctions the overuse of Islamist ideology and at least symbolically champions gender equality. Obviously, the supply and demand model thus cannot entirely explain the diverging paths in nomination of women between the PJD and the MB, as it turns a blind eye to the context-related factors from which quotas and the authoritarian regime's approach to gender equality seem to stand out most.

\section{External Interference in the Form of Quotas and State Feminism in Morocco}

Though sometimes only a superficial instrument that helps ease the gender inequalities in politics, quotas are extremely important in facilitating the entry of increasing numbers of women into politics as candidates and, eventually, as MPs. ${ }^{69}$ We identify several types of gender quotas. The first is the party quota, the success of which is contingent upon the choices of particular parties as well as the type of electoral system in place. Party quotas are problematic because unless all parties adopt them and/or some win substantial majorities, the critical mass is unlikely to be reached. The second type is the legislated or constitutional quota system, in which a number of the seats, or a percentage of the legislature, is reserved for women. This usually significantly boosts the number of women in parliament but does not necessarily alter society's acceptance of women's representation. In Arab countries, the most common type of women quota is the reserved seats system. As already mentioned, while it helps fast-track women into parliament, its lasting effects are rather unconvincing because it does not necessarily lead to a consolidation of a strong constituency for women running on a separate list.

In the Moroccan case, the gender quotas acted as an extremely important external intervention by King Muhammad VI, enlarging the space for the legislative recruitment of women. These efforts were finalized in an informal

68 Rapp, "The Challenges and Opportunities", 20-21.

69 Caul, “Women's Representation”, 92. 


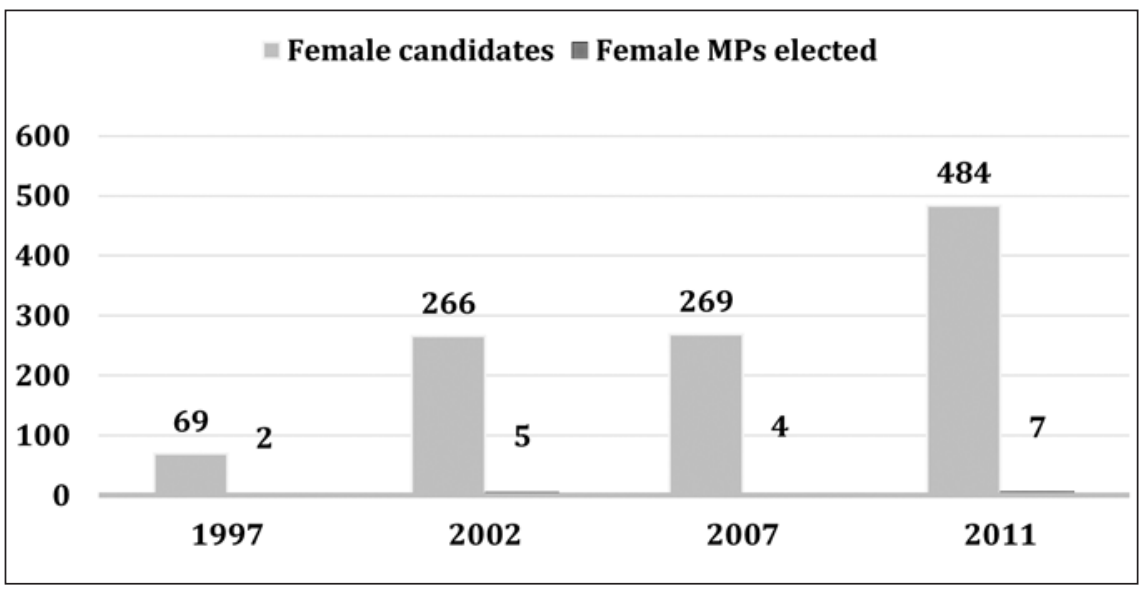

GRAPH 2 Electoral success of female candidates in local districts in Moroccan elections ${ }^{\mathrm{a}}$ a Meradith, Female Representation, 8.

agreement with the political parties in 2002, reserving 30 of the 325 seats in the lower house for female candidates. ${ }^{70}$ After the electoral reform of 2011, the number of seats has been increased to 60 out of $395{ }^{71}$ Additionally, women have also been able to win several seats in the newly introduced reserved seats for youth. As a result, the proportion of women increased from 10 per cent in the 2007 elections to 17 per cent in the 2011 elections. Prior to the adoption of quotas, only 0.6 per cent of parliamentary seats were held by women. Quotas in Morocco are based on closed party lists in a proportional system, while the rest of the chamber is elected in 92 local districts. However, reserved seats have not been able to successfully challenge the male-dominated political system due to a very slim margin of additional women (about 2 per cent) elected via local district seats. ${ }^{72}$

Additionally, as a result of the low district magnitude proportional electoral system, which allocates leftover seats to smaller parties, political parties fight over a relatively small number of seats and therefore usually nominate the strongest candidates in local districts, who are rarely women (Table 1). In the

\footnotetext{
70 Sadiqi, "Morocco", 326.

$71 \quad$ Hanane Darhour and Drude Dahlerup, "Sustainable representation of women through gender quotas: A decade's experience in Morocco", Women's Studies International Forum 41, no.2 (2013), 132-42, on 137, doi: 10.1016/j.wsif.2013.04.008.

72 Anouk Lloren, “Gender Quotas in Morocco: Lessons for Women's Descriptive and Symbolic Representation", Representation 50, no.4 (2014), 527-38, on 530, doi:10.1080/00344893 .2014.979224.
} 
TABLE 1 Proportion offemale candidates in Moroccan parliamentary elections ${ }^{\text {a }}$

\begin{tabular}{lllll}
\hline Election year & $\begin{array}{l}\text { Total number } \\
\text { of candidates } \\
\text { on district } \\
\text { lists }\end{array}$ & $\begin{array}{l}\text { \% of female } \\
\text { candidates on } \\
\text { district lists }\end{array}$ & $\begin{array}{l}\text { \% of districts } \\
\text { headed by a } \\
\text { woman }\end{array}$ & $\begin{array}{l}\text { National lists } \\
\text { female } \\
\text { candidates }\end{array}$ \\
\hline & & & & no gender \\
1997 & 3288 & $2 \%$ & N/A & quotas \\
2002 & 5865 & $5 \%$ & $3 \%$ & 697 \\
2007 & 6691 & $4 \%$ & $3 \%$ & 780 \\
\hline
\end{tabular}

a Darhour and Dahlerup, "Sustainable representation", 138.

last elections, only around 4 per cent of the local electoral lists were headed by women. ${ }^{73}$ Most frequently, nominated women were allocated the last places on the slate, which perpetuates women's marginalization in Moroccan politics. However, quotas still remain a necessary tool to engage women in political life.

\section{Resulting Political Representation of Women from the PJD}

As previously noted, state feminism and the newly granted venues for political representation of women in Morocco have mainly empowered conservative women. Thus paradoxically, as in many parliaments worldwide, the party with the most female representatives is not necessarily one with a pro-feminist stance. ${ }^{74}$ In the 2002 election, the PJD nominated 36 women in a constituency vote and 30 in a party list for the reserved seats. Out of these, the party was able to secure six female MPs, which constituted the highest number in modern Moroccan history. This success was repeated during the 2007 elections. ${ }^{75}$ In the following local elections, they were able to secure the third highest number of successful candidates, despite running in only 16 per cent of the districts. ${ }^{76}$

73 National Democratic Institute, Final Report on the Moroccan Legislative Elections (Washington, DC, 2011) <http://www.ndi.org/files/Morocco-Final-Election-Report-o61812-ENG. pdf>.

74 Darhour and Dahlerup, "Sustainable Representation", 137.

75 Rapp, "Challenges and Opportunities", 21-22.

76 Wegner, Islamist Opposition, 55 . 
TABLE 2 Electoral success of female candidates from the PJD in Morocco ${ }^{\text {a }}$

\begin{tabular}{llllll}
\hline & $\begin{array}{l}\text { Total number } \\
\text { of seats for } \\
\text { PJD }\end{array}$ & $\begin{array}{l}\text { Elected } \\
\text { women }\end{array}$ & $\begin{array}{l}\text { PJD women in } \\
\text { district seats }\end{array}$ & $\begin{array}{l}\text { Elected } \\
\text { women }\end{array}$ & $\begin{array}{l}\text { PJD women in } \\
\text { reserved seats }\end{array}$ \\
\hline 2002 & $42(13 \%)$ & 5 & $2(40 \%)$ & 30 & $4(13 \%)$ \\
2007 & $47(14 \%)$ & 4 & $0(0 \%)$ & 30 & $6(20 \%)$ \\
2011 & $107(27 \%)$ & 7 & $2(29 \%)$ & 60 & $16(27 \%)$ \\
2016 & $125(32 \%)$ & 10 & $4(40 \%)$ & 71 & $20(28 \%)$ \\
\hline
\end{tabular}

a Darhour and Dahlerup, "Sustainable representation", 136.

Obviously, out of all the Moroccan parties, the Islamist PJD has the largest absolute number of women in parliament and the highest male-to-female ratio of its MPs (14.3 per cent of total seats in 2002, 12.7 per cent in 2007, 16.8 per cent in 2011, and 19.2 per cent in 2016). ${ }^{77} \mathrm{PJD}$ women have also won numerous seats in municipal councils around the country. The sharp increase in the PJD's female membership and their electoral encouragement by the leaders was therefore in large part due to their perceived electoral utility (Table 2).

Although the PJD has nominated hundreds of female candidates in elections, it seems to rely on women MPs as 'tokens', or proxies who enlarge its presence in parliament and, thanks to the strict party discipline, may help deliver voting for the selected bills. To illustrate the Islamists' reluctance to give genuine decision-making power to women, consider the make-up of the latest PJD's coalition government. In the historic first Islamist-led coalition government in 2011, only one woman was appointed a minister. This was highly criticized by women's organizations in Morocco as a huge departure from the previous government, which had included seven women. ${ }^{78}$ Female PJD members generally defended this decision by stressing the democratic method of nomination, where "the women of the party participate [...] and the appointment of one female minister [...] was a democratic choice made by all the

77 Interparliamentary Union, "мовоссо: Majliss-annouwab (House of Representatives)" <http://www.ipu.org/parline/reports/2221_A.htm>.

78 Samia Errazzouki, "From Opposition to Puppet: Morocco's Party of Justice and Development", Jadaliyya, 24 November $2012<$ http://www.jadaliyya.com/pages/index/8590/fromopposition-to-puppet_morocco $\% \mathrm{E} 2 \% 80 \% 99 \mathrm{~s}-\mathrm{p}>$. 
members of the party, regardless of gender."79 This decision may have been taken through democratic means, albeit in a party which strongly supports the patriarchal status quo. Furthermore, criticism has been levelled at the selection of female candidates on the reserved women's list. The fact that the party's central organs are responsible for choosing female candidates gives the upper echelons a great leverage to filter what kind of women are placed in parliamentary seats, which may easily prevent more liberal women from assuming positions of power. PJD women mostly attain seats in parliament through these quota arrangements. Only in a few cases have female candidates been able to secure a constituency vote.

The number of PJD candidates and female representatives in parliament has increased drastically since the PJD's first electoral engagement. Although in theory this would be a positive development for women, two problems arise. First, the increased number of MPs resulted entirely from quotas and state feminism, as only a few women attained seats in the election for local districts. Therefore, this trend reflects a systematic change neither in society-wide attitudes nor in the political marginalization of women. Nonetheless, their everincreasing numbers may serve as a symbolic driver to prompt other women to fight for political participation and representation in the Moroccan parliament. Second, the representative claims of female PJD members can be often considered illiberal or anti-feminist. This coincides with the Moroccan political system, which drives female parliamentarians to stick with their political affiliations. As a result, the women's section and female MPs only translate the party agenda on women and hardly ever propose any concrete legal changes to Moroccan women's status quo. ${ }^{80}$ Nonetheless, their conservatism is so far contested by the strong position of the reformist king, by the secular parties, and by the active feminist movement in the country.

\section{Lack of External Interference in the Form of Quotas and State Feminism in Egypt}

In contrast to the Moroccan case, the institutional framework in Egypt, especially regarding quotas, has not been so stable or linear. These external interventions were applied ad hoc and in an unequal fashion, mirroring the struggle of former President Mubārak for popular legitimacy. In effect, the representation of women in Egypt has been constantly low, never exceeding 13 per cent of

\footnotetext{
79 Meriem El Haitami, "Women in Morocco: political and religious power", Open Democracy, 31 January 2013 <https://www.opendemocracy.net/505o/meriem-el-haitami/women-inmorocco-political-and-religious-power >.

$80 \quad$ Sater, "Changing Politics", 737.
} 
TABLE 3 Electoral success of female candidates in Egypt ${ }^{\mathrm{a}}$

\begin{tabular}{lllll}
\hline $\begin{array}{l}\text { Election } \\
\text { year }\end{array}$ & $\begin{array}{l}\text { Number of } \\
\text { women elected }\end{array}$ & $\begin{array}{l}\text { Number of } \\
\text { women } \\
\text { appointed }\end{array}$ & $\begin{array}{l}\text { Total number of } \\
\text { women in } \\
\text { parliament }\end{array}$ & $\begin{array}{l}\text { Total } \\
\text { percentage }\end{array}$ \\
\hline 1979 & 33 & 2 & 35 & $9 \cdot 7$ \\
1984 & 35 & 1 & 36 & $7 \cdot 8$ \\
1987 & 14 & 4 & 18 & 3.9 \\
1990 & 7 & 3 & 10 & 2.2 \\
1995 & 9 & 4 & 13 & 2 \\
2000 & 7 & 4 & 11 & 2.4 \\
2005 & 4 & 5 & 9 & 2 \\
2010 & 63 & 1 & 64 & 12.7 \\
2011 & 9 & 2 & 11 & 2 \\
\hline
\end{tabular}

a Tadros, "Quotas", 91.

the legislature (Table 3). In the 1979-84 period, the Egyptian regime implemented reserved list quotas, which resulted in 9.7 per cent (1979) and 7.8 per cent (1984) representation of women in the parliament. Abrogation of this law brought a setback in terms the percentage of female MPs. The reserved seat quotas were revived during the 2010 election, raising the percentage of women in the legislature to 12.7 per cent, only to be abolished a year later.

Female candidates in Egypt have also suffered from a bad reputation, associated with the fact that women MPs were almost exclusively members of the regime's National Democratic Party (NDP, al-Hizb al-Wațan̄ Al-Dìmūqrāțī) or members of parties affiliated with the current president, 'Abd al-Fattāh al-Sīsī. For instance, in 2005, during the freest and fairest (relatively speaking) election in pre-Arab Spring Egypt, all four women elected were from the NDP, and the other three independents later joined the NDP in parliament. ${ }^{81}$ Nonetheless, the ruling party only nominated six women for the election, and other oppositional parties followed suit. Money, the political influence of male party leaders, and social pressure on female candidates all contributed to the low

$81 \quad$ Jeremy M. Sharp, "Egypt: 2005 Presidential and Parliamentary Elections", Congressional Research Service, 16 January 2005, 5 <http://www.mit.edu/afs.new/sipb/contrib/wikileaks-crs/wikileaks-crs-reports/RS22274.pdf>. 
incidence of female candidates in electoral districts. ${ }^{82}$ In the breakthrough democratic election of 2011, women candidates represented around 31 per cent of all candidates. However, most of them ran as independents. Women therefore finally made up only 6 per cent of the party and coalition lists. ${ }^{83}$ The new electoral law crafted by the Supreme Council of the Armed Forces (SCAF, alMajlis al-A'lā lil-Quwwāt al-Musallaha) was considered one of the biggest challenges to women's representation. The law abolished the previous system of reserved seats and opted for compulsory inclusion of at least one woman on each district list. Nonetheless, the law did not specify the desired position of female candidates on the lists, which resulted in a situation where in 70 per cent of the cases, political parties fielded women in the last places. The final proportion of women in 2012 legislature thus reached only 2 per cent. Although Islamists won almost 70 per cent, only four women from the Muslim Brotherhood's Freedom and Justice Party (FJP) secured seats in the parliament. The other parties which received only a small share of seats were able to push through relatively more women - three were from the liberal Hizb al-Wafd and one from the Reform and Development Party (Hizb al-Ișlāh wa-l-Tanmiya). Additionally, two were appointed by the SCAF. ${ }^{84}$ Therefore, the final drop from 12 to 2 per cent after the Arab Spring represented a major setback for women in Egypt. This proportion was extremely low even by the standards of Arab states, which averaged 10.7 per cent of women parliamentarians (counting only those Arab states which have parliaments). ${ }^{85}$ Even more striking is the fact that the low candidacy of women on party lists is not restricted to Islamists. Almost all ideological camps in the country placed a similar number of women on their lists (Graph 3).

Furthermore, the MB's official position towards the women quotas was uncompromisingly negative, with its spokesman, 'Ișām al-'Aryān, stressing that it

$82 \quad$ Kristen Anne Belle-Isle, "Quotas in Egypt: understanding the implementation and discourse about introducing quotas for women in the people's assembly between women's groups, members of parliament and political parties from 2005-2012" (PhD diss., The American University in Cairo, 2014), 86.

83 Julie Tomlin, "Egypt Election: No Revolution for Women", The Guardian, 1 December 2011 <http://www.guardian.co.uk/world/2011/dec/o1/egypt-revolution-women-elections? newsfeed $=$ true $>$.

84 Ahmed Bekhet, "Islamist and Secularist Women in Egyptian Politics: Convergence or Divergence?" (PhD diss., Georgia Southern University, 2014), 76.

85 "Women's Empowerment in the Middle East and Worldwide: Statement by UN Women Executive Director Michelle Bachelet", UN Women, 20 April $2012<\mathrm{http}$ ://www.unwomen. $\mathrm{org} / \mathrm{en} / \mathrm{news} /$ stories/2012/4/women-s-empowerment-in-the-middle-east-and-worldwide $>$. 


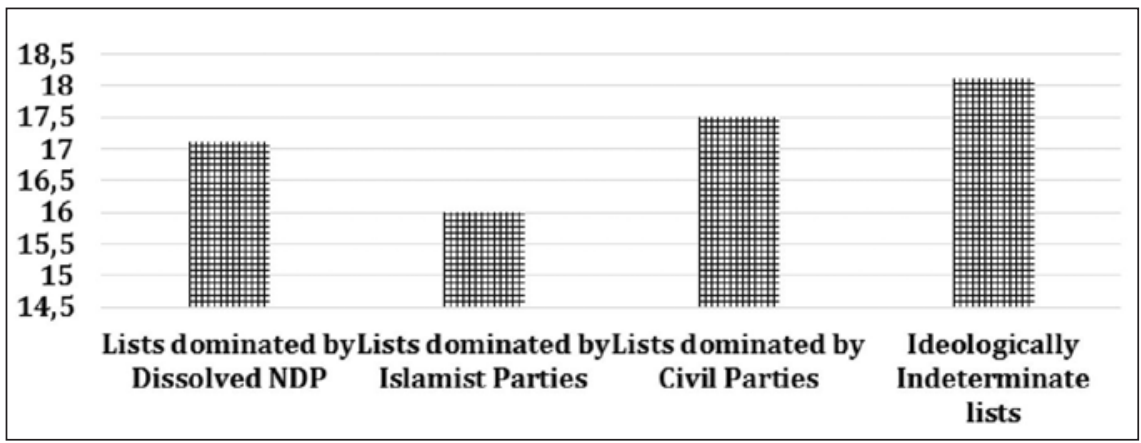

GRAPH 3 Total candidacy of women on all ideological lists in the 2011 election ${ }^{\mathrm{a}}$

a "She and the Elections: Mentoring on the Ground with Candidates 2011/2012." Report by Nazra for Feminist Studies, undated <http://nazra.org/sites/nazra/files/attachments/nazra_she_ and_elections_report_april2012_en.pdf $>$.

divided society and went against embedded cultural norms, and as such was a Western import. He further stated that Islam had already given women enough equality with men, thus making these measures unnecessary. ${ }^{86}$ This line of reasoning is also reflected by the women of the MB's FJP party. 'Izza al-Jarf (Azza Al-Garf), a female MP from the FJP, noted that the incremental success of women in the 2012 election may translate to an ever-increasing number of women in the future, without being associated with "special treatment." She claimed "the quota is a form of discrimination, while citizenship is the proper foundation. Women will convince the people and win their confidence through hard work, social service and great efficiency." 87 Another female MP from the FJP, Hudā Ghaniya, reiterated similar sentiments by claiming that since all citizens under Islamist constitution have "complete rights", championing gender-specific rights would be unnecessary. ${ }^{88}$ However, it should be noted that secular female politicians also object to reserved seat quotas, albeit in a different fashion. They stress that these types of quota further weaken the primary role of Egyptian political parties in women's political empowerment. Reserved seats are seen as being contrary to popular mobilization and the building of

\footnotetext{
86 Belle-Isle, "Quotas in Egypt", 99.

87 "Azza Al-Garf: Freedom and Justice Party Prepares Women for Forthcoming Parliamentary Poll", IkhwanWeb: The Muslim Brotherhood's Official English Website, 9 January 2013 $<$ http://www.ikhwanweb.com/article.php?id=30545>.

88 "Huda Ghaniya: New Constitution Will Make Women Worthy First-Class Citizens", IkhwanWeb: The Muslim Brotherhood's Official English Website, 1 August $2012<\mathrm{http} / / / \mathrm{www}$. ikhwanweb.com/article.php?id=30218>.
} 
trust within a certain constituency and forcing women to rely on the backing by powerful business elites. Female representatives from the Tajammu party, for instance, argued that it would be more desirable to adopt a strictly proportional electoral system empowering political parties while adopting quotas for women on the lists. ${ }^{89}$

\section{Resulting Political Representation of Women from the Muslim Brotherhood}

Evidently, in stark contrast to the experience of the Islamist PJD party in Morосco, the мв has historically fielded only a few female candidates in parliamentary elections. Following its establishment in 1928, the movement put forward its first candidates in the 1940 s but nominated its first female candidate, although she was subsequently unsuccessful, only in 2000. In the 2005 elections, the мв suggested it would field between 14 and 21 female candidates. This step was reverted following the regime's pre-election security crackdowns, reducing the final number of female candidates to only one, Makāim al-Dayrī, a professor of Arabic literature at Al-Azhar University. ${ }^{90}$ Interestingly, at the time, even the liberal Hizb al-Wafd nominated only one woman. In the 2010 elections, which introduced reserved seats for 63 women, the мв nominated more female candidates in order to maximize their chances of winning the parliamentary seats. ${ }^{91}$ However, the 2010 election was the most fraudulent to date, and the мв was unable to secure a single seat. After the Egyptian revolution in 2011, the MB's FJP party fielded women in almost all electoral districts, in accordance with the new electoral law. They were mostly placed in the bottom half or third of the lists. Only in two constituencies, al-Daqhaliyya (Dakahlia) and Qalūbiyya, did women run in the top spots. In comparison, the leftist Egyptian Bloc nominated nine female candidates at the top of the list and the centrist $a l$ - $A d l$ party, eight women. ${ }^{92}$ At the extreme right, the salafi Islamist party Hizb al-Nür (al-Nour Party) conformed to the legal requirements concerning female candidates, even though these candidates were rumoured to include only the mothers or the sisters of party members and were always at

\footnotetext{
89 Tadros, "Quotas", 94.

9o Abdel-Latif, In the Shadow, 16.

91 Samer Shehata, "Egypt: The Founders", in The Islamists are Coming: Who They Really are, ed. Robin Wright (Washington, DC: Us Institute of Peace Press, 2012), 26.

92

"Which Egyptian parties represent women and Copts and young people?", Democratizing the New Egypt, 7 December $2011<$ http://democratizingegypt.blogspot.sk/2011/11/whichegyptian-parties-represent-women.html>.
} 
the last position in the list. The party even replaced female candidates' photographs with flowers on the party logo. ${ }^{93}$

In this respect, the MB stood halfway between the socialists in Egypt, who tended to empower women the most, and the salafis, who rejected women's political participation altogether. In terms of absolute numbers, the FJP nominated more female candidates than any other party in Egypt. In the end, four out of nine female parliamentarians in the short-lived parliament were from the FJP. ${ }^{94}$ The Constituent Assembly, tasked with writing a new constitution in 2012, had a similar gender composition. Out of 100 members, 66 were from Islamist parties, and only 3 women out of 6 represented the FJP. The assembly's conservative composition was reflected in the final constitutional text's regression on women's rights. ${ }^{95}$ In order to placate the resentment from secularist circles, after the FJP's candidate Muhammad Mursì assumed presidency, he appointed one woman, Dr. Bākīnām al-Sharqāwī, a political science professor at Cairo University, to his presidential advisory team. ${ }^{96}$ However, he also appointed 'Imād 'Abd al-Ghafür, the ultraconservative founder of the Hizb al-Nür party, as "presidential adviser for social outreach." 97

Decades of community-based political experience and thousands of women actively working within the Brotherhood's Muslim Sisters section have created a much larger pool of potential female candidates compared to any other political party in Egypt. The fact that the мв has been fielding so few of these women in actual elections is therefore quite significant. This shows that female activists in the мв have not been voicing a demand to assume leadership positions or that they have not collectively mobilized around this issue. On the other hand, male leaders justify this lack of opportunity for women's political participation in terms of the regime's repression. Due to the security harassments of $\mathrm{MB}$ candidates, women often failed to gain the permission of their family to participate in elections. The need of the husband's consent in order

93 Laila El-Baradei and Dina Wafa, "Women in the Second Egyptian Parliament Post the Arab Spring: Do they think they stand a chance?", Journal of International Women's Studies 14, no.3 (2013), 42-63, $45<$ http://vc.bridgew.edu/jiws/voli4/iss3/4>.

94 Çavdar, "Islamist rationality", 599.

95 The assembly's view of gender equality is reflected in Article 36 of the constitution: "The State shall take all measures to establish the equality of women and men in the areas of political, cultural, economic and social life, as well as all other areas, insofar as this does not conflict with the rulings of Islamic sharia."

96 Bekhet, "Islamist and Secularist", 8.

97 Lally Weymouth, "Egypt From the Inside", Slate, 31 May $2013<$ http://www.slate.com/arti cles/news_and_politics/foreigners/2013/05/emad_abdel_ghafour_heads_egypt_s_watan_ party_the_salafist_leader_who_advises.html >. 
for the Brotherhood to support the female candidate indicates that the concept of male dominance at home, as preached by the movement's founder, Hasan al-Bannā, is still applicable in the мв. ${ }^{98}$ While the active agency of a few women from the Mв, including Jīhān al-Ḥalafāwī, Makārim al-Dayrī, and Amānī Abū al-Faḍl, should not be overlooked, their success depended on their individual efforts and abilities, not on an institutionalized process of empowering women inside the мв. ${ }^{99}$

Islamists' critics claim that the nomination of a few women for national and local elections serves merely as a PR move by the Brotherhood. This is evidenced by the fact that women are theoretically allowed to run as candidates for the Brotherhood in external elections but cannot participate in the movement's internal elections. They can only serve to further the propaganda of the мв and lead other sisters, not the Brotherhood in general. As in the case of the $\mathrm{PJD}$, prominent Islamist women tend to present ambivalent stances on gender issues. On the one hand, they speak of the need to enlarge the room for manœuvre for women within the political system. On the other hand, regarding women's roles, their rights, and selected social issues, they advocate highly conservative views. This rise of conservative female politicians with regressive ideas about women's rights seems to be a global phenomenon. Such women can also be found in Western democracies, particularly among republicans in the United States. ${ }^{100}$ Although they generally benefited from the advocacy of gender equality, they tend to attack liberal feminists and universal human rights on most accounts. The difference is that, unlike in Morocco, where the feminist movement is quite powerful, in Egypt conservative Islamist women represent the political mainstream. How this observation affects the overall pattern of generally low female candidacy from Islamist movements in Egypt deserves further elaboration.

\section{Concluding Remarks}

The study of female candidacy and subsequent political representation is a fruitful way of understanding the evolution of patriarchy in the MENA region.

98 Mariz Tadros, “The Muslim Brotherhood's Gender Agenda: Reformed or Reframed?", IDS Bulletin 42, no.1 (2011), 88-98, on 94, doi:10.1111/j.1759-5436.2011.00204.x.

99 Abdel-Latif, In the Shadow, 15.

100 Nina Burleigh, "Is Azza Al Garf Egypt's Michele Bachmann?", Slate, 19January $2012<$ http:// www.slate.com/articles/double_x/doublex/2012/01/azza_al_garf_is_she_egypt_s_answer_ to_michele_bachmann_html>. 
Patriarchy entails male dominance and male centricity, and although it is rooted in the social sphere, it does have political dimensions and manifestations, extending to key areas of political contestation such as the composition of the legislature and political parties. The study of women as candidates in elections provides insight into how and under what conditions patriarchy may evolve in times of societal transition. ${ }^{101}$ Hence studies of changing patterns in legislative recruitment of women in Islamist parties - the most prominent opposition movements in the region - are thus not only informative empirically and theoretically but also relevant for policymaking.

While the female membership of both the Moroccan PJD and the Egyptian мв has been constantly on the rise, only a small proportion of these women have in fact been allowed to run as candidates in elections. In this regard, the PJD fared much better than the MB. As the results of this study suggest, the reason is that the party is relatively decentralized and institutionalized and therefore able to increase the manœuvring space for women within its decision-making structures. It has two women on its general secretariat and numerous women on the intra-party Shūrā Council, as well as in its local bureaus. On the other hand, the Mв relies on the Muslim Sisters exclusively as recruiters and mobilizers during the elections. This difference mainly flows from the lack of institutionalization and the centralized, oligarchic character of the Brotherhood's leadership. The low bargaining power of women from the мв when compared to the PJD results in extremely low numbers of female candidates in elections. Additionally, the conservative gender norms in Egyptian society and the movement, as well as the weakening of social forces with progressive gender agendas (such as the feminist movement), have meant that the $\mathrm{MB}$, unlike the PJD, has not been pressured to reconsider, justify, or be held accountable for gender discriminatory practices within its legislative recruitment.

While the article has used the supply and demand model to analyse candidate selection, it has argued that external interventions, such as quotas and authoritarian state feminism, act outside the scope of the model and thus challenge its applicability. Furthermore, as argued, the poor incidence of female candidates from the MB is not unique to Islamists. In Egypt, most political parties nominate very few women. This has often been rationalized by state repression towards opposition candidates, which might endanger female candidates. In the end, the government's repression of the $\mathrm{MB}$, the lack of state feminism, and the inconsistent application of quotas by the Egyptian regime have all helped to divert attention from the issue of gender inequalities, contributing to the perpetuation of patriarchy inside the Brotherhood's structure 
and eventually in legislative recruitment as well. In Morocco, where the elections are freer and more competitive, the application of intra-party gender quotas and the broadening of participation for women inside the party have been motivated by the overall pattern in other political parties with which the PJD competes. The Moroccan Islamist Party also recognizes the value of female candidates, especially given the reserved quotas system in place and the regime's encouragement of female candidacy during elections. ${ }^{102}$

102 This contribution was supported by the VEGA (Slovak Scientific Grant Agency) of the Ministry of Education of the Slovak Republic (ME SR) under the contract No. VEGA 1/0770/16 "Representation of women in the $\mathrm{V}_{4}$, Sub-Saharan Africa and MENA regions." 